\title{
Effect of bleaching agent extracts on murine macrophages
}

\author{
Aletéia M. M. Fernandes ${ }^{1,2}$ • Polyana G. F. Vilela ${ }^{3}$ - Marcia C. Valera ${ }^{4}$ - Carola Bolay $^{5}$. \\ Karl Anton Hiller ${ }^{5}$. Helmut Schweikl ${ }^{5}$. Gottfried Schmalz ${ }^{5,6}$
}

Received: 9 February 2017 / Accepted: 7 November 2017 /Published online: 1 December 2017

(C) Springer-Verlag GmbH Germany, part of Springer Nature 2017

\begin{abstract}
Objectives The aim of this study was to evaluate the cytotoxicity and the influence of bleaching agents on immunologically cell surface antigens of murine macrophages in vitro. Materials and methods RAW 264.7 cells were exposed to bleaching gel extracts ( $40 \%$ hydrogen peroxide or $20 \%$ carbamide peroxide) and different $\mathrm{H}_{2} \mathrm{O}_{2}$ concentrations after 1 and 24-h exposure periods and 1-h exposure and 23-h recovery. Tests were performed with and without $N$-acetyl cysteine (NAC) and buthionine sulfoximine (BSO). Cell viability was determined by MTT assay. The expression of surface markers CD14, CD40, and CD54 with and without LPS stimulation was detected by flow cytometry, while the production of
\end{abstract}

Gottfried Schmalz

Gottfried.Schmalz@ukr.de

1 Department of Health Sciences, Endodontics Division, Nove de Julho University (UNINOVE), São Paulo, Brazil

2 Department of Health Sciences, Anatomy and Pathology Division, Anhanguera University, Vergueiro, 235/249 — Liberdade, São Paulo, SP 01504-000, Brazil

3 Department of Bioscience and Oral Diagnosis, Microbiology Division, São José dos Campos Dental School, State University of São Paulo, UNESP, Av. Eng. Francisco José Longo, 777—Jardim Sao Dimas, São José dos Campos, SP 12245-000, Brazil

4 Department of Restorative Dentistry, Endodontic Division, São José dos Campos Dental School, State University of São Paulo UNESP, Av. Eng. Francisco José Longo, 777—Jardim Sao Dimas, São José dos Campos, SP 12245-000, Brazil

5 Department of Conservative Dentistry and Periodontology, University Hospital Regensburg, University of Regensburg, Franz-Josef-Strauß-Allee 11, 93053 Regensburg, Germany

6 Department of Periodontology, University of Bern, Freiburgstrasse 7, CH-3010 Bern, Switzerland
TNF- $\alpha$ was measured by ELISA. Statistical analysis was performed using the Mann-Whitney $U$ test $(\alpha=0.05)$.

Results Extracts of bleaching agents were cytotoxic for cells after a 1-h exposure; cells could not recover after $24 \mathrm{~h}$. This effect can be mitigated by the antioxidant NAC and increased by $\mathrm{BSO}$, an inhibitor of glutathione (GSH) synthesis. LPS stimulated expression of all surface markers and TNF- $\alpha$ production. Exposure to bleaching agent extracts and $\mathrm{H}_{2} \mathrm{O}_{2}$ leads to a reduction of TNF- $\alpha, \mathrm{CD} 14$, and CD40 expression, while the expression of CD54 was upregulated at non-cytotoxic concentrations. Whereas NAC reduced this effect, it was increased in the presence of BSO.

Conclusions Extracts of bleaching agents were irreversibly cytotoxic to macrophages after a 1-h exposure. Only the expression of CD54 was upregulated. The reactions are mediated by the non-enzymatic antioxidant GSH.

Clinical relevance The addition of an antioxidant can downregulate unfavorable effects of dental bleaching.

Keywords Cytotoxicity · Immunology · Dental bleaching · Cytokines $\cdot$ Hydrogen peroxide

\section{Introduction}

Tooth whitening has become widespread in dentistry, especially after the introduction of home bleaching procedures in the 1980s of the last century [1]. Hydrogen peroxide is the most commonly used bleaching agent [2], applied directly or as released from sodium perborate or carbamide peroxide [3]. Whitening is achieved due to the permeability of dental hard tissues for bleaching substances, such as hydrogen peroxide [4]. The oxidation of chromogens by hydrogen peroxide results in less or non-colored compounds [5]. However, a consequence of this permeability is the diffusion of hydrogen 
peroxide towards the dental pulp [2, 6, 7]. The amount of $\mathrm{H}_{2} \mathrm{O}_{2}$ reaching the pulp chamber after 40 min of exposure to a $38 \%$ hydrogen peroxide bleaching substance was reported to be $2.15 \mu \mathrm{g}( \pm 0.22 \mu \mathrm{g})$ in a human teeth model with 3-3.5$\mathrm{mm}$ enamel and dentin thickness [8].

While some authors consider the use of bleaching agents a safe procedure [9], others believe that hydrogen peroxide may irritate tissues like the dental pulp. Tooth sensitivity after tooth bleaching has been reported consistently, which, however, normally disappears within a few days or weeks [10]. In cell culture experiments, it was shown that $0.36 \pm 0.04 \mathrm{mmol} / \mathrm{l}$ of $\mathrm{H}_{2} \mathrm{O}_{2}$ exposure for $24 \mathrm{~h}$ caused a $50 \%$ decrease of human gingival fibroblasts [11] and $0.22+0.03 \mathrm{mmol} / \mathrm{l}$ in rat kidney tubules [12]. Cell viability of human gingival fibroblasts was also decreased by half after 90-s exposure to $15 \% \mathrm{H}_{2} \mathrm{O}_{2}$ [13].

Using odontoblast-like cells (MDPC-23) in an artificial pulp chamber with an enamel/dentin thickness of $5.6 \mathrm{~mm}$, it could also be shown that hydrogen peroxide in concentrations of 35\% may cause cell damage, reducing cell viability and alkaline phosphatase activity (ALP) [14]; moreover, a similar study showed that this bleaching agent was able to produce severe morphological alterations in this cell line and only cell membrane remnants were observed in cell-free areas, showing that local toxicity caused the death of a large number of MDPC-23 cells $[15,16]$.

Hydrogen peroxide is able to interact directly with DNA, causing oxidative damage at concentrations of 125,250 , and $500 \mu \mathrm{M}$ in mouse leukemia cells, and a concentration of $500 \mu \mathrm{M}$ hydrogen peroxide was shown to induce nucleosomal DNA fragments indicative of apoptotic cell death [17]. Moreover, $250 \mu \mathrm{M}$ of hydrogen peroxide induced loss of viability in respiratory epithelial cells, associated with DNA damage and reduction in ATP content, which was related with necrotic cell death [18]. According to Filho et al., the exposure of $10 \%$ carbamide peroxide to oral epithelium may not cause but may accelerate non-detected in situ carcinomas [19]. However, according to IARC [20], hydrogen peroxide is not classified as a carcinogen to humans (group 3), considering that there is inadequate evidence in humans and limited evidence in experimental animals for the carcinogenicity of this agent.

Some studies reported an association of oxidative stress with inflammation [21, 22]. The inflammatory response is a main body's defense mechanism [23]. Macrophages play an important role in this process, initiating and maintaining the immune responses, including degradation of extracellular matrix by producing a large number of matrix metalloproteinases and also chemoattractants that recruit additional leukocytes and secret different cytokines, such as tumor necrosis factor- $\alpha$ (TNF- $\alpha)[24,25]$. In the context of the defense against pathogenic bacteria, certain pattern recognition receptors like the TLR4 system are able to identify lipopolysaccharides (LPS) from gram-negative bacterial cell walls and to eliminate bacteria through the activation of the immune system. To initiate the corresponding intracellular reaction cascade, additional cell surface receptors such as CD14 are necessary to induce the activation in response to LPS. LPS binding to its receptor CD14/ TLR4 initiates a complex signaling cascade, which leads to the activation of several transcription factors that control macrophage activation [26, 27]. Macrophages also act as important accessory cells in the activation of the adaptive immune system by behaving as antigenpresenting cells (APCs). The antigen-presenting process requires the expression of major histocompatibility complex (MHC) class II molecules and costimulatory molecules like CD80, CD86, or CD40, since the induction of an effective $\mathrm{T}$ cell response is a result of $\mathrm{MHC} / \mathrm{T}$ cell receptor interaction and costimulatory molecules on $\mathrm{T}$ cells and macrophages. CD54 (= ICAM 1) is important in leukocyte traffic (transendothelial migration to sites of inflammation), functioning as a costimulatory molecule for $\mathrm{T}$ cell activation. Its expression is upregulated in response to inflammatory mediators, including proinflammatory cytokines, hormones, and cellular stresses [28, 29].

In previous studies [30], we evaluated the expression of cell surface markers and the release of the pro-inflammatory cytokine TNF- $\alpha$ in response to the exposure of LPSstimulated macrophages to monomers of dental resin composites. Interestingly, the monomers reduced LPS-induced expression of TNF- $\alpha$ and CD14 at non-cytotoxic concentrations, but increased the expression of CD54. In other studies [31, 32], the same monomers increased the concentration of reactive oxygen species (ROS) and possibly hydrogen peroxide in particular. In these studies, RAW 264.7 mouse macrophages were used because of their relevant function in inflammation processes [33]. Glutathione (GSH) as a major non-enzymatic antioxidant is essential to reduce cellular oxidative stress and maintain cellular redox balance [34]. The GSH concentrations can experimentally be reduced by buthionine sulfoximine (BSO), which selectively inhibits of GSH synthesis [35]. On the other hand, $N$-acetyl cysteine (NAC) is a precursor of GSH synthesis and acts as an antioxidant by itself counteracting increasing concentrations of ROS [35].

Although a number of studies have shown cell damaging effects of hydrogen peroxide-based bleaching agents [36], little information is available on the direct influence of bleaching agents on essential functions of cells of the immune system. Therefore, we hypothesized that peroxides and related dental bleaching agents could interfere with the expression of cell surface antigens essential for cell communication and adhesion as well as the production of the pro-inflammatory cytokine TNF- $\alpha$ in murine macrophages. Furthermore, the role of 
oxidative stress in these processes was investigated using the antioxidant NAC and BSO as an inhibitor of GSH synthesis.

\section{Material and methods}

\section{Test materials}

In this study, the following substances were used: $N$-acetyl cysteine (Sigma GmbH, Steinheim, Germany), L-buthionine sulfoximine (Sigma GmbH, Steinheim, Germany), TEGDMA (triethylene glycol dimethacrylate, Sigma GmbH, Steinheim, Germany), hydrogen peroxide $\left(\mathrm{H}_{2} \mathrm{O}_{2}\right)$ stock solution of $10 \%$, (Pharmacy, University Hospital Regensburg, Germany), and lipopolysaccharide (LPS, Escherichia coli, serotype 055:B5, Sigma GmbH, Steinheim, Germany). Hydrogen peroxide stock solution was stored in the dark at $4{ }^{\circ} \mathrm{C}$ and freshly prepared each week. Two bleaching gel products have been tested; for composition and manufacturer information, see Table 1. The design of the study with the experimental and the reference groups as well as the exposure scenarios and the endpoints measured is shown in Fig. 1.

\section{Cell cultures and extract preparation}

RAW 264.7 mouse macrophages (ATCC TIB71) were kept in routine culture in RPMI 1640 medium containing L-glutamine, sodium-pyruvate, and $2.0 \mathrm{~g} / 1 \mathrm{NaHCO}_{3}$ supplemented with $10 \%$ fetal bovine serum (FBS) and penicillin-streptomycin. In order to obtain conditioned medium (= extract), the bleaching agents were covered with complete cell culture medium for $1 \mathrm{~h}$ at $37{ }^{\circ} \mathrm{C}$ at a ratio of $4 \mathrm{~g}$ per $20 \mathrm{ml}(0.2 \mathrm{~g}$ per $1 \mathrm{ml})$ of fresh medium, according to the American Society for Testing Materials (ASTM) [37] and ISO 10993-5 [38]. The material in the conditioning medium was vortexed and then centrifuged at $14,000 \mathrm{rpm}$ for $1 \mathrm{~min}$ to form a pellet on the bottom. The supernatant, which did not show any visible color change, was used as the material extract immediately after preparation to prepare serial dilutions in cell culture medium. $\mathrm{H}_{2} \mathrm{O}_{2}$ was diluted from the $10 \%$ stock solution in cell culture medium.

\section{Cytotoxicity}

In total, $2 \times 10^{3}$ cells were seeded into each well of a 96well plate (Sigma-Aldrich, Germany) and incubated for $48 \mathrm{~h}$ at $37^{\circ} \mathrm{C}$ in a humidified atmosphere containing $5 \%$ $\mathrm{CO}_{2}$. The unconditioned medium was removed, and cell cultures were then exposed to $200 \mu \mathrm{l}$ of serial dilutions of the bleaching agent extracts (20\% CP and $40 \% \mathrm{HP}$ ) or culture medium as a negative control. Various concentrations of hydrogen peroxide were used as a positive control. The experiments were performed both in the presence or in the absence of $5 \mathrm{mM}$ NAC added $1 \mathrm{~h}$ before exposure or $50 \mu \mathrm{M}$ BSO (L-buthionine sulfoximine) added $20 \mathrm{~h}$ before exposure. Cells were exposed to the extracts (1) for $1 \mathrm{~h},(2)$ for $24 \mathrm{~h}$, and (3) for $1 \mathrm{~h}$, replaced by fresh media and incubated for further $23 \mathrm{~h}(1 \mathrm{~h}$ plus 23 -h recovery period). Cell viability was determined using the 3-(4,5-dimethylthiazol-2-yl)-2,5-diphenyl-tetrazolium bromide (MTT) assay. For this, the medium was replaced by $100 \mu \mathrm{l} /$ well of a solution of MTT (Sigma, Steinheim, Germany) $(0.5 \mathrm{mg} / \mathrm{ml})$ in phosphate-buffered saline (PBS), and cells were incubated at $37^{\circ} \mathrm{C}$ for $1 \mathrm{~h}$ in a $5 \% \mathrm{CO}_{2}$ atmosphere. The MTT solution was removed and replaced by $100 \mu \mathrm{l} /$ well of DMSO for $20 \mathrm{~min}$, and then, optical density in each well was measured spectrophotometrically (Infinite F200; Tecan, Crailsheim, Germany) at a wavelength of $540 \mathrm{~nm}$. Optical density readings from cultures exposed to extracts or $\mathrm{H}_{2} \mathrm{O}_{2}$ dilutions were normalized to untreated control cultures (=
Table 1 Composition of tested bleaching gels, information provided by the manufacturers

\begin{tabular}{ll}
\hline Bleaching gel composition & \\
\hline Opalescence PF 20\% & \multicolumn{1}{c}{ Opalescence Boost $40 \%$} \\
Ultradent Products, South Jordan, Utah, USA & \multicolumn{1}{c}{$\begin{array}{c}\text { (Lot 138237) } \\
\text { (Lot L092) }\end{array}$} \\
$20 \%$ Carbamide peroxide & $40 \%$ Hydrogen peroxide \\
Potassium nitrate & $3 \%$ Potassium nitrate \\
Fluoride 1100 ppm & $1.1 \%$ Fluoride \\
Glycerin & \\
Water & \\
Xylitol & \\
Carbomer & \\
PEG-300 & \\
Sodium hydroxide & \\
EDTA &
\end{tabular}


Fig. 1 Study design with the experimental and the reference groups as well as the exposure scenarios and the recorded endpoints

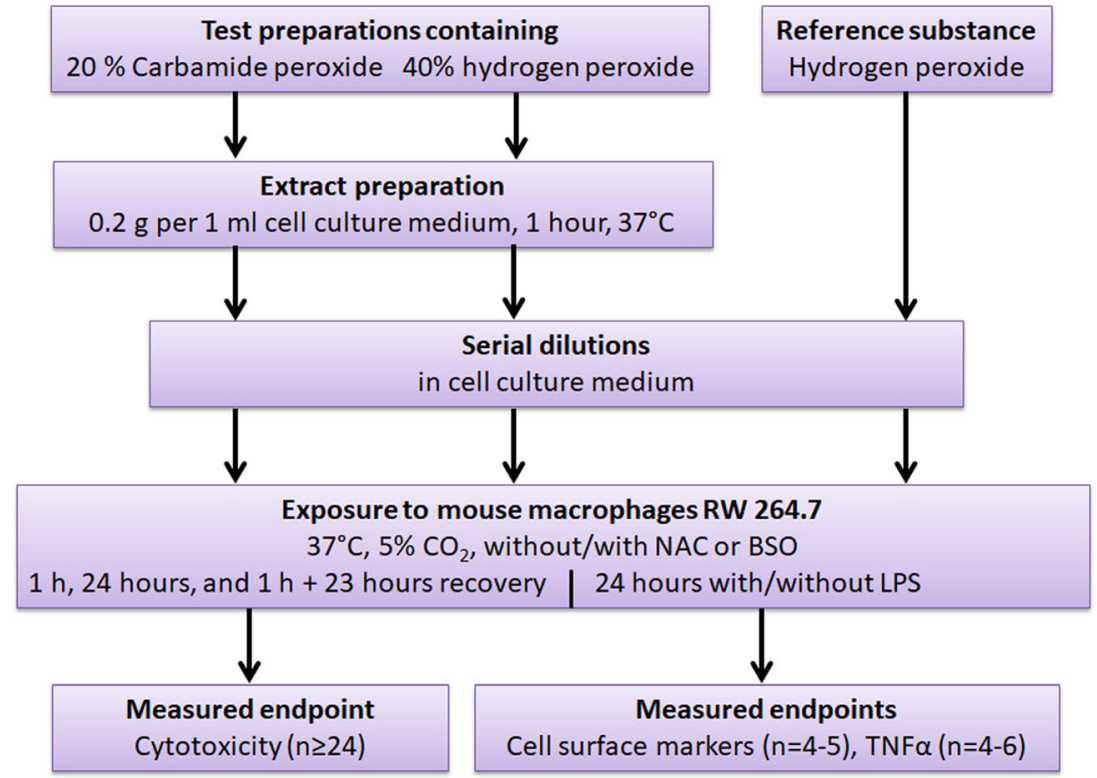

$100 \%)$ and are reported as relative optical density. In each experiment, 8 wells were used for each treatment and at least three independent experiments were performed. Medians and the upper and lower quartile (25/75 percentiles) were computed and statistically analyzed using the Mann-Whitney $U$ test (SPSS 20.0, SPSS, Chicago, IL, USA) for pairwise comparisons among groups at the $\alpha=0.05$ level of significance. For multiple comparisons, the Error Rates method was applied.

For each dilution series, relative optical density values were fitted to linear, general, non-linear, and transition equations (TableCurve 2D V 5.01, SYSTAT Software Inc., San Jose, CA, USA). From fitted curves, the concentration at which $50 \%$ of cells survived $\left(\mathrm{EC}_{50}\right)$ was derived together with corresponding $95 \%$ confidence limits. Fits with a correlation coefficient $r^{2} \geq 0.8$ were considered. Differences between the $\mathrm{EC}_{50}$ values were statistically analyzed using the Tukey interval method.

\section{Flow cytometry}

A suspension of $5 \times 10^{4}$ cells in $3 \mathrm{ml}$ of culture medium was plated into each well of a 6 -well plate and incubated for $48 \mathrm{~h}$ at $37{ }^{\circ} \mathrm{C}$ in a humidified atmosphere containing $5 \% \mathrm{CO}_{2}$. Then, cells were exposed to different dilutions of extracts of the bleaching agents (20\% CP and $40 \% \mathrm{HP})$ and of $\mathrm{H}_{2} \mathrm{O}_{2}$ in the presence and absence of $5 \mathrm{mM} \mathrm{NAC}$ or $50 \mu \mathrm{M}$ BSO as described above. In some experiments, cells were also exposed to LPS at $0.1 \mu \mathrm{g} / \mathrm{ml}$ (Escherichia coli, serotype 055:B5, Sigma $\mathrm{GmbH}$, Steinheim, Germany) in order to stimulate the expression of immune cell surface markers or TNF- $\alpha$. After 24-h incubation, cells were washed and suspended in
FACS buffer $\left(1 \times\right.$ CMF-PBS, $1 \%$ FBS, $\left.0.1 \% \mathrm{NaN}_{3}\right)$. Expression of cell surface markers was analyzed by flow cytometry. Cell staining was performed using FITC-conjugated or PE-conjugated monoclonal antibodies (mAbs; BD Pharmingen, Heidelberg, Germany): anti-mouse anti-CD14 (clone rmC5-3), anti-mouse anti-CD40 (clone 3/23), and anti-mouse anti-CD54 (clone 3E2). Cells were stained with trypan blue (1:10) to assess cell vitality. Cells were incubated with $\mathrm{mAbs}$ for $30 \mathrm{~min}$ at $4{ }^{\circ} \mathrm{C}$ or trypan blue for $5 \mathrm{~min}$. After washing and suspension in FACS buffer, stained cells were analyzed by FACSDIVA software. Each treatment was performed in at least four independent experiments with each data point acquired from at least $2 \times 10^{4}$ cells. For each experiment, surface antigen expression was determined from mean fluorescence intensities normalized to untreated LSPstimulated controls $\left(2 \times 10^{4}=100 \%\right)$. Medians and the upper and lower quartile $(25 / 75$ percentiles) were calculated and were statistically analyzed using the Mann-Whitney $U$ test (SPSS 20.0, SPSS, Chicago, IL, USA) for pairwise comparisons among groups at the $\alpha=0.05$ level of significance. For multiple comparisons, the Error Rates method was applied.

\section{Production of TNF- $\alpha$}

The production of the cytokine TNF- $\alpha$ was determined in the same cultures analyzed for surface antigen expression. Cell culture supernatants were collected, and amounts of TNF- $\alpha$ were determined using ELISA kits (BD Pharmingen, Heidelberg, Germany) according to the manufacturer's instructions. All plates were read in a multi-well spectrophotometer (Infinite F200; Tecan, Crailsheim, Germany), using Magellan version 6.2 software. The lower detection limits 
using standard curves were $15.7 \mathrm{pg} / \mathrm{ml}$. Relative amounts of cytokines were calculated from individual values obtained in four independent experiments and normalized to LPS-treated cell cultures $(=100 \%)$. Medians and the upper and lower quartile (25/75 percentiles) were calculated and were statistically analyzed using the MannWhitney $U$ test (SPSS 20.0, SPSS, Chicago, IL, USA) for pairwise comparisons among groups at the 0.05 level of significance. For multiple comparisons, the Error Rates method was applied.

\section{Results}

\section{Cytotoxicity}

Dilutions of original extracts of bleaching agents and the $\mathrm{H}_{2} \mathrm{O}_{2}$ were cytotoxic on RAW 264.7 cells, and the extent of effects varied between the materials, their dilutions, and additives used. As expected, higher concentration of extracts of the bleaching agents caused a higher reduction in cell viability as is shown exemplarily for the 1-h exposure in Fig. 2a. The $\mathrm{EC}_{50}$ data, which represent the equitoxic concentrations/ dilutions of the extracts for 50\% reduction in cell viability, was for the $40 \%$ hydrogen peroxide bleaching gel more than 16 times (1-h exposure, 0.000864 vs. 0.0142 ) or 32 times (24-h exposure, 0.000393 vs. 0.0103 ) lower than the $\mathrm{EC}_{50}$ for the $20 \%$ carbamide peroxide gel (extract dilutions) (Fig. 2b). The $\mathrm{EC}_{50}$ for $\mathrm{H}_{2} \mathrm{O}_{2}$ under these test conditions ranged at $0.0089 \%$. $\mathrm{EC}_{50}$ for the test extracts and of $\mathrm{H}_{2} \mathrm{O}_{2}$ did not significantly or only slightly differ between the 1-h exposure/23-h recovery on the one side and the 24-h exposure on the other (Fig. 2b). These results show that cells after 1-h exposure did not recover from treatment under these experimental conditions. The addition of the antioxidant NAC did considerably increase the viability of the cells at the given concentrations, whereas BSO decreased the viability (Fig. 2a). This is also apparent from the $\mathrm{EC}_{50}$ data (Fig. 2b). The differences between the $\mathrm{EC}_{50}$ concentrations from exposures with and without NAC were statistically significant. On the other side, the GSH inhibitor BSO reduced significantly the $\mathrm{EC}_{50}$ indicating an increase in cytotoxicity for the $40 \%$ hydrogen peroxide gel and the $\mathrm{H}_{2} \mathrm{O}_{2}$ (Fig. 2b).

\section{Cell surface markers}

Only small amounts of CD14 and CD40 could be detected without LPS stimulation (data not shown). LPS stimulated the expression of all measured cell surface markers especially CD14 and CD40 (Fig. 3a, b). After exposure of the LPSstimulated cells with $\mathrm{H}_{2} \mathrm{O}_{2}$, CD14 expression was reduced to non-detectable levels at concentrations of $0.005 \% \mathrm{H}_{2} \mathrm{O}_{2}$ (Fig. 3a). An extract dilution of 1:100 of the $20 \%$ carbamide peroxide bleaching gel caused total depression of CD14 expression, as did an extract dilution of 1:1000 for the $40 \%$ hydrogen peroxide gel (Fig. 3a). Similar results were observed for the LPS-stimulated expression of CD40 (Fig. 3b). Results for CD54 expression for both, with and without LPS stimulation, are shown in Fig. 4. Again, a decrease of CD54 expression can be observed for $\mathrm{H}_{2} \mathrm{O}_{2}$ at the $0.005 \%$ level, especially without LPS stimulation and for cytotoxic concentrations of the bleaching gel extracts (Fig. 4a, b).

Interestingly, we found an increase of CD54 expression after exposure to $0.004 \% \mathrm{H}_{2} \mathrm{O}_{2}$, and more pronounced is this effect for the LPS-stimulated cells. This concentration is at the cytotoxic concentration range (Fig. 2). A significant increase in CD54 expression can be observed after exposure to the different concentrations of the bleaching gel extracts (Fig. 4a, b).

The addition of the antioxidant NAC induced inverse effects on CD54 expression depending on the concentration of $\mathrm{H}_{2} \mathrm{O}_{2}$ or bleaching gel extracts (Fig. $4 \mathrm{a}, \mathrm{b}$ ). NAC reduced the CD54 increase especially in the LPS-stimulated cells after exposure to the $\mathrm{H}_{2} \mathrm{O}_{2}$ dilutions and to the bleaching gel extracts in the non-cytotoxic concentration range. In contrast, NAC increased CD54 expression in the cytotoxic concentration range of $\mathrm{H}_{2} \mathrm{O}_{2}$ or bleaching gel extracts (Fig. 4a, b). The GSH inhibitor BSO further increased the CD54 expression, again especially in the LPS-treated cultures. This effect is clearly visible for the $\mathrm{H}_{2} \mathrm{O}_{2}$ dilutions and for some concentrations of bleaching gel extracts (Fig. 4b).

\section{Production of TNF- $\alpha$}

Without LPS stimulation, no TNF- $\alpha$ could be determined (data not shown). With LPS stimulation (Fig. 5), $\mathrm{H}_{2} \mathrm{O}_{2}$ increased TNF- $\alpha$ production at non-cytotoxic concentrations $(0.002 \%)$, but TNF- $\alpha$ was reduced at higher (cytotoxic) concentrations. Data for the bleaching gel extracts are inconsistent. A significant influence of non-cytotoxic concentrations of $\mathrm{H}_{2} \mathrm{O}_{2}$ or bleaching gel extracts on TNF- $\alpha$ release was not detected, but at cytotoxic concentrations, TNF- $\alpha$ production significantly decreased (Fig. 5). Again, the antioxidant NAC reduced both the stimulation of TNF- $\alpha$ and its depression for all test substances. The GSH inhibitor BSO had the reverse effect.

\section{Discussion}

The aim of the present study was to evaluate the reaction of the immune system after the exposure to $\mathrm{H}_{2} \mathrm{O}_{2}$ containing bleaching gels and to evaluate the effect of an antioxidant (NAC) and a glutathione inhibitor (BSO). As macrophages play a central role in immune reactions, these cells have been used as target cells. The same cells with and without LPS 

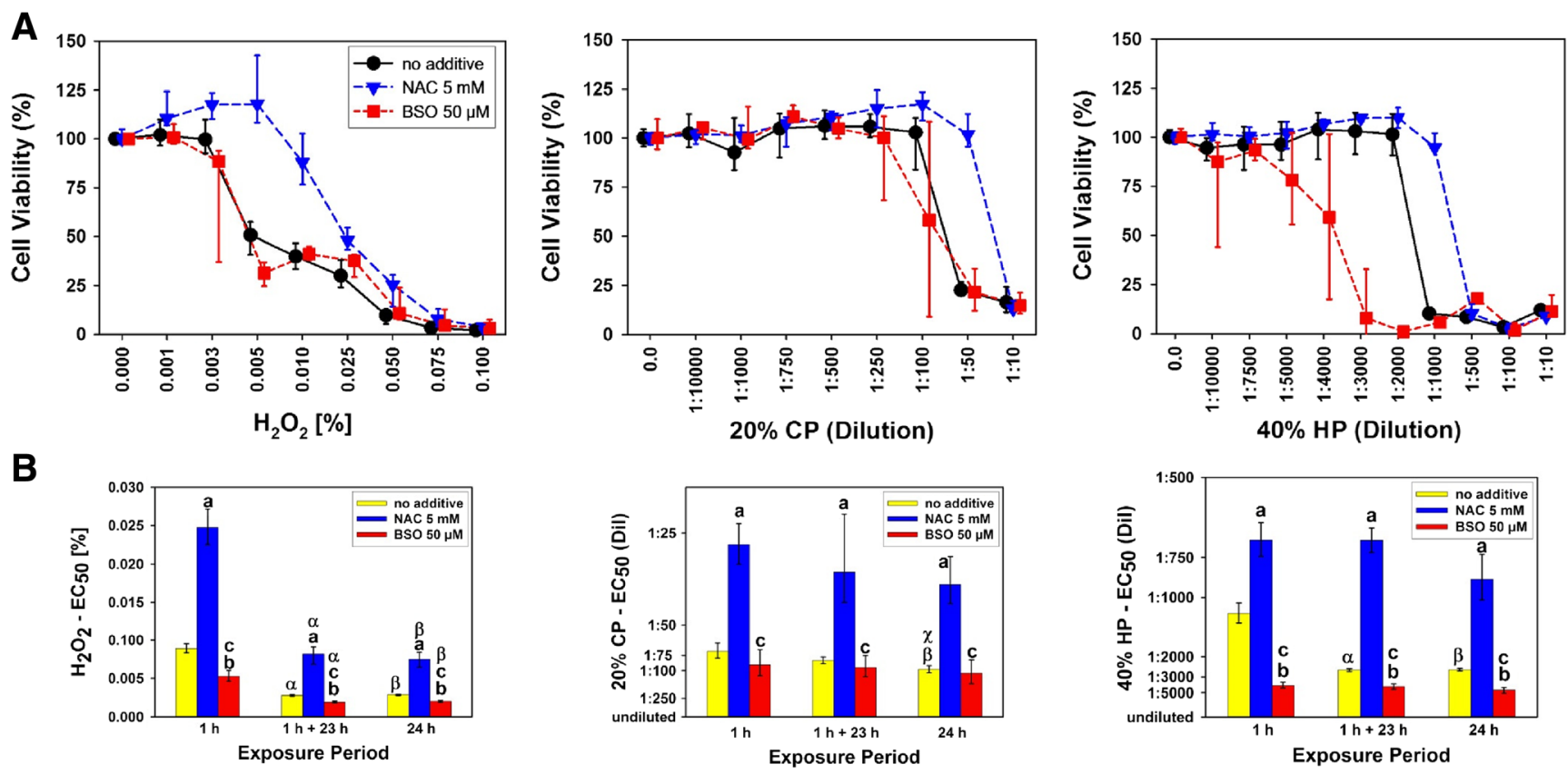

Fig. 2 Viability of RAW 264.7 macrophages after exposure to the bleaching agents Opalescence PF 20\% (20\% CP) or Opalescence Boost $40 \%(40 \% \mathrm{HP})$ or hydrogen peroxide $\left(\mathrm{H}_{2} \mathrm{O}_{2}\right)$. A Cells were exposed to serially diluted extracts of bleaching agents or increasing concentrations of $\mathrm{H}_{2} \mathrm{O}_{2}$ for $1 \mathrm{~h}$ in the presence or absence of NAC $(5 \mathrm{mM})$ or BSO $(50 \mu \mathrm{M})$. Original optical density readings were normalized to untreated control cell cultures $(100 \%)$. Symbols represent median values (with 25 and $75 \%$ percentiles) summarized from four independent experiments and eight repeats for each dilution or concentration $(n>24)$. B Bars show half-maximum effective dilutions of bleaching agent extracts or concentrations of $\mathrm{H}_{2} \mathrm{O}_{2}\left(\mathrm{EC}_{50}\right)$ which were calculated from fitted dose-response curves obtained after various exposure periods as described in "Material and methods" section. Differences between the median $\mathrm{EC}_{50}$ values were statistically analyzed using the Tukey interval method. Dil.: dilution, NAC: $N$-acetyl cysteine, BSO:

buthionine sulfoximine. "a" denotes significant difference between median $\mathrm{EC}_{50}$ values observed in cultures treated with $20 \% \mathrm{CP}, 40 \% \mathrm{HP}$, or $\mathrm{H}_{2} \mathrm{O}_{2}$ (no additive) and cultures exposed in the presence of NAC. "b" denotes significant difference between median $\mathrm{EC}_{50}$ values observed in cultures treated with $20 \% \mathrm{CP}, 40 \% \mathrm{HP}$, or $\mathrm{H}_{2} \mathrm{O}_{2}$ (no additive) and cultures exposed in the presence of BSO. "c" denotes significant difference between median $\mathrm{EC}_{50}$ values observed in cultures treated with $20 \% \mathrm{CP}$, $40 \% \mathrm{HP}$, or $\mathrm{H}_{2} \mathrm{O}_{2}$ in the presence of NAC or BSO. " $\alpha$ " denotes significant difference between median $\mathrm{EC}_{50}$ values observed in cultures treated for $1 \mathrm{~h}$ and cultures treated for $1 \mathrm{~h}$ with a subsequence 23 -h recovery period $(1+23 \mathrm{~h}) . " \beta$ denotes significant difference between median $\mathrm{EC}_{50}$ values observed in cultures treated for $1 \mathrm{~h}$ and cultures treated for $24 \mathrm{~h}$. " $\chi$ denotes significant difference between median $\mathrm{EC}_{50}$ values observed in cultures treated for $1 \mathrm{~h}$ with a subsequent 23 -h recovery period $(1+23 \mathrm{~h})$ and cultures treated for $24 \mathrm{~h}$

exposure have been used in former studies testing the effects of dental monomers [30, 39, 40].

One bleaching agent contained-according to the information from the manufacturer- $40 \%$ hydrogen peroxide, which directly acts as bleaching substance. In contrary, the second preparation contained $20 \%$ carbamide peroxide, which liberates hydrogen peroxide to a maximum of about $6.7 \%$ of the preparation [41]. Carbamide peroxide is a stable complex that breaks down in contact with water to release hydrogen peroxide [5]. Both preparations also contain other substances, and in order to modify the effect of the hydrogen peroxide component. $\mathrm{H}_{2} \mathrm{O}_{2}$ dilutions have been used as controls.

In this study, the $\mathrm{EC}_{50}$ for the $\mathrm{H}_{2} \mathrm{O}_{2}$ exposure for $24 \mathrm{~h}$ was $0.0028 \% \mathrm{H}_{2} \mathrm{O}_{2}$, which corresponds to $0.812 \mathrm{mmol} / \mathrm{l}$. Reichl et al. [11] reported an $\mathrm{EC}_{50}$ of $0.36 \pm 0.04 \mathrm{mmol} / \mathrm{l}$ for $\mathrm{H}_{2} \mathrm{O}_{2}$ in human gingival fibroblasts. This indicates that human gingival fibroblasts react similar to $\mathrm{H}_{2} \mathrm{O}_{2}$ than murine macrophages.

The observed cytotoxicity of the bleaching agents is in agreement with data from the literature, e.g., showing that $35-40 \% \mathrm{H}_{2} \mathrm{O}_{2}$ bleaching preparations are cytotoxic in immortalized odontoblasts [42] or in primary culture human pulp fibroblasts [43]. Even low concentrations (10-20\% carbamide peroxide) were cytotoxic to immortalized odontoblasts [2], human dermal fibroblasts [44], and human dental follicle stem cells [44].

In our study, the cytotoxicity of the $40 \%$ hydrogen peroxide bleaching gel extract is 16 to 32 times higher than the $20 \%$ carbamide peroxide gel extract. However, the potential maximum release of $\mathrm{H}_{2} \mathrm{O}_{2}$ is only a factor of 5 higher in the $40 \%$ hydrogen peroxide gel (40 vs. $6.7 \%$ ). Furthermore, the $\mathrm{EC}_{50}$ data of the gels are much higher than corresponding data from pure $\mathrm{H}_{2} \mathrm{O}_{2}$ assuming that all available $\mathrm{H}_{2} \mathrm{O}_{2}$ from the gels would be present in the extract. Thus, the toxicity of the gel extracts does not only depend on the maximum potential $\mathrm{H}_{2} \mathrm{O}_{2}$ content or release. Other factors influence cytotoxicity, like extract 

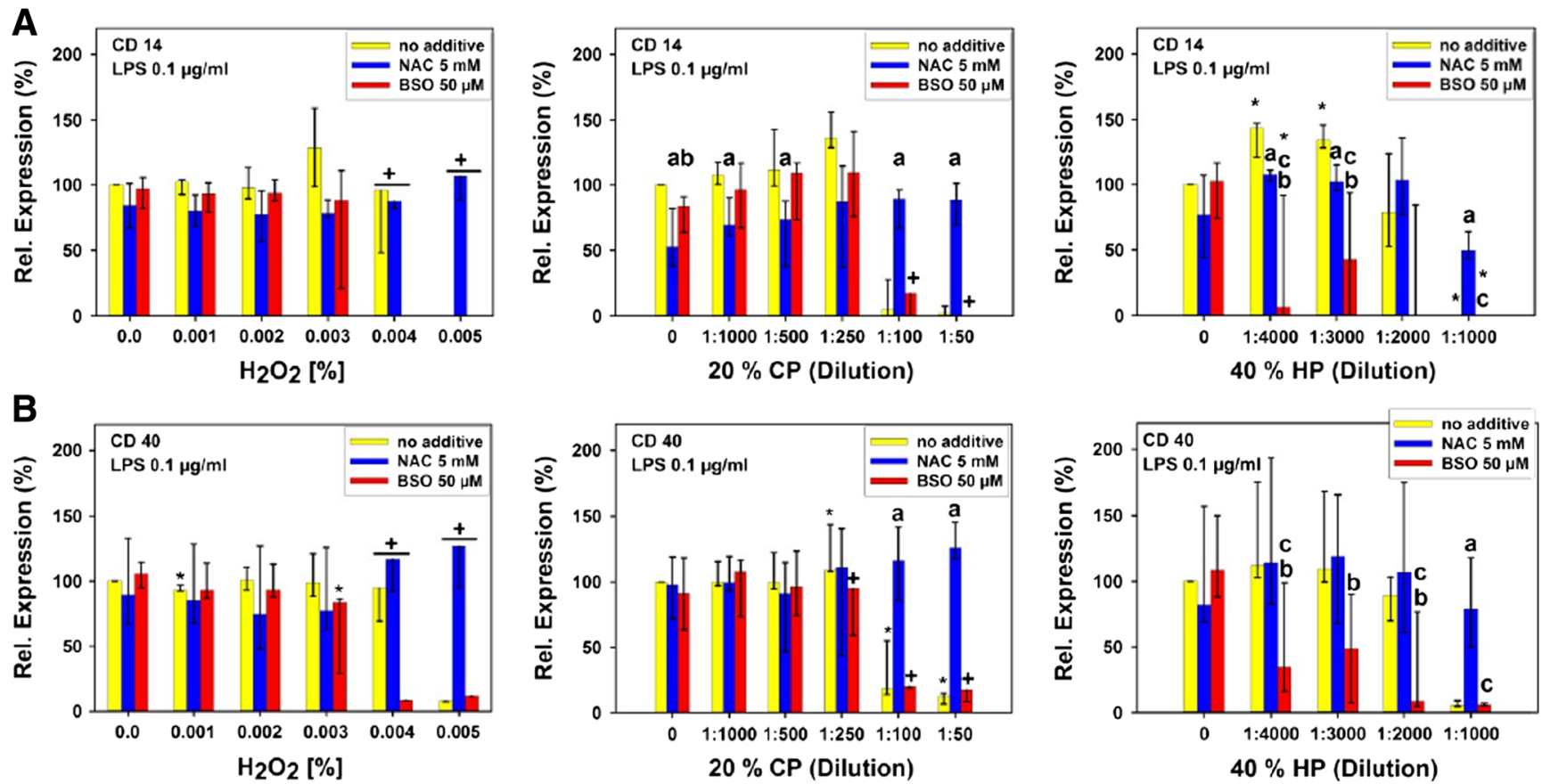

Fig. 3 CD14 (A) and CD40 (B) expression in RAW 264.7 macrophages. Cells were exposed to the bleaching agents Opalescence PF 20\% (20\% $\mathrm{CP}$ ) or Opalescence Boost $40 \%(40 \% \mathrm{HP})$ or $\mathrm{H}_{2} \mathrm{O}_{2}$ for $24 \mathrm{~h}$ in the presence of LPS. Bars represent medians (plus 25/75 percentiles) calculated from individual histograms $(n=4-5)$ normalized to LSP-stimulated controls (100\%). "a" denotes significant difference between median values obtained with $20 \% \mathrm{CP}, 40 \% \mathrm{HP}$, or $\mathrm{H}_{2} \mathrm{O}_{2}$ (no additive) and cultures exposed in the presence of NAC. "b" denotes significant difference between median values obtained with $20 \% \mathrm{CP}, 40 \% \mathrm{HP}$, or $\mathrm{H}_{2} \mathrm{O}_{2}$ (no additive) and cultures exposed in the presence of BSO. "c" denotes significant difference between median values obtained with $20 \% \mathrm{CP}, 40 \%$ $\mathrm{HP}$, or $\mathrm{H}_{2} \mathrm{O}_{2}$ in the presence of either NAC or BSO. "*" denote significant difference between median values obtained from untreated controls or controls in the presence of NAC or BSO and cultures treated with various matching dilutions of $20 \% \mathrm{CP}$ or $40 \% \mathrm{HP}$ extracts or concentrations of $\mathrm{H}_{2} \mathrm{O}_{2}$. "+" denotes no statistical analyses because of low sample size (23) obtained in four to five independent experiments as a consequence of severe cytotoxic effects conditions or the retarded release of $\mathrm{H}_{2} \mathrm{O}_{2}$ by carbamide peroxide [45].

Interestingly, cell damage after 1-h exposure to $\mathrm{H}_{2} \mathrm{O}_{2}$ and to both bleaching gel extracts was irreversible, since cells did not recover after removal of conditioned medium and replacement by fresh culture medium. To the best of our knowledge, similar experiments have not been performed so far.

In the present study, we found no detectable expression of CD14 and CD40 without LPS stimulations, but increased expression after LPS stimulation. CD54 was detected without LPS stimulation but also increased after LPS stimulations. This is in line with previous studies [30] evaluating the immunological effect of TEGDMA with and without LPS on RAW 264.7 murine macrophages. D'Anto et al. [26] confirmed these results. However, at long period exposure time, CD54 was downregulated by LPS.

The decrease of CD14 and CD40 expression after exposure to $\mathrm{H}_{2} \mathrm{O}_{2}$ and bleaching gel extracts at cytotoxic concentrations is in line with the results of Eckhardt et al. [30] after exposure to cytotoxic concentrations of TEGDMA. The results of D'Anto et al. [26] demonstrated that the expression of CD14 and CD40 was significantly increased in the presence of $0.1 \mathrm{mM}$ nickel chloride (non-toxic concentration) in cell cultures co-stimulated with $0.1 \mathrm{mg} / \mathrm{ml}$ LPS. However, when a high concentration of nickel chloride $(0.5 \mathrm{mM})$ was used for $48 \mathrm{~h}, \mathrm{CD} 14$ and CD40 were downregulated, decreasing the expression of these cell surface markers. In the present study, no upregulation of CD14 and CD40 was found and the downregulation is only a consequence of increased cytotoxicity.

Results for CD54 expression showed a different pattern. At non-cytotoxic concentrations of $\mathrm{H}_{2} \mathrm{O}_{2}$ or bleaching gel extract dilutions, CD54 expression was increased without LPS stimulation, but even more so with LPS stimulation. This is in line with the results of Eckhardt et al. [30], who demonstrated that LPS and TEGDMA (even in high concentrations) were able to increase the levels of CD54 up to $81 \%$ when compared to LPS alone stimulation after $24 \mathrm{~h}$. D'Anto et al. [26] also observed that only the expression of CD54 was still significantly upregulated in LPS-stimulated cell cultures treated with $0.5 \mathrm{mM}$ nickel chloride for $48 \mathrm{~h}$, showing a different behavior than other surface antigens. CD54 is an adhesion molecule which is expressed on vascular endothelium and on leucocytes in response to several inflammatory stimulations. Upregulation of CD54 expression increases cell adhesion and cell-cell interaction. It 

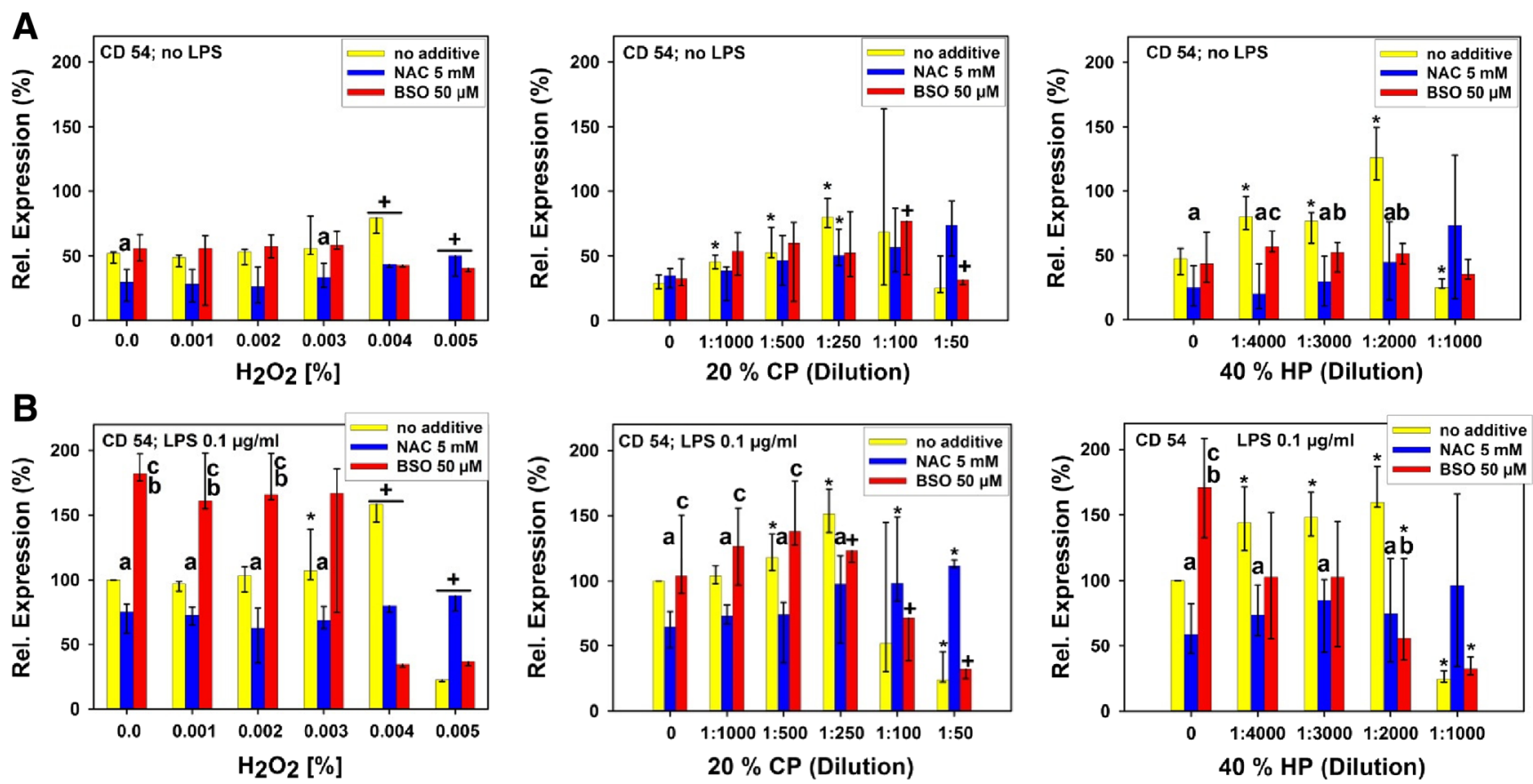

Fig. 4 CD54 expression in RAW 264.7 macrophages in the absence (A) or presence of LPS stimulation (B). Cells were exposed to the bleaching agents Opalescence PF 20\% (20\% CP) or Opalescence Boost 40\% (40\% $\mathrm{HP}$ ) or $\mathrm{H}_{2} \mathrm{O}_{2}$ for $24 \mathrm{~h}$. Bars represent median (plus $25 / 75$ percentiles) calculated from individual histograms $(n=4-6)$ normalized to LSPstimulated controls (100\%). "a" denotes significant difference between median values obtained with $20 \% \mathrm{CP}, 40 \% \mathrm{HP}$, or $\mathrm{H}_{2} \mathrm{O}_{2}$ (no additive) and cultures exposed in the presence of NAC. " $b$ " denotes significant difference between median values obtained with $20 \% \mathrm{CP}, 40 \% \mathrm{HP}$, or $\mathrm{H}_{2} \mathrm{O}_{2}$

(no additive) and cultures exposed in the presence of BSO. "c" denotes significant difference between median values obtained with $20 \%$ CP, $40 \%$ $\mathrm{HP}$, or $\mathrm{H}_{2} \mathrm{O}_{2}$ in the presence of either NAC or BSO. "*" denote significant difference between median values obtained from untreated controls or controls in the presence of NAC or BSO and cultures treated with various matching dilutions of $20 \% \mathrm{CP}$ or $40 \% \mathrm{HP}$ extracts or concentrations of $\mathrm{H}_{2} \mathrm{O}_{2}$. "+"denotes no statistical analyses because of low sample size (2-3) obtained in four to five independent experiments as a consequence of severe cytotoxic effects

facilitates the attachment of leukocytes to endothelial cells and allows for the transendothelial migration of leukocytes at inflammatory sites [46].

In the present study, non-cytotoxic $\mathrm{H}_{2} \mathrm{O}_{2}$ concentrations increased TNF- $\alpha$ production in LPS-stimulated cells, after exposure to bleaching gels, although data were inconsistent.

However, our results are in agreement with those from Eckhard et al. [30], who demonstrated an upregulation of the production of TNF- $\alpha$ by TEGDMA only when it was associated with LPS and in non-toxic concentrations. TNF- $\alpha$, released by monocytes and macrophages in response to several stimuli, acts as a major inflammation mediator [47]. As a
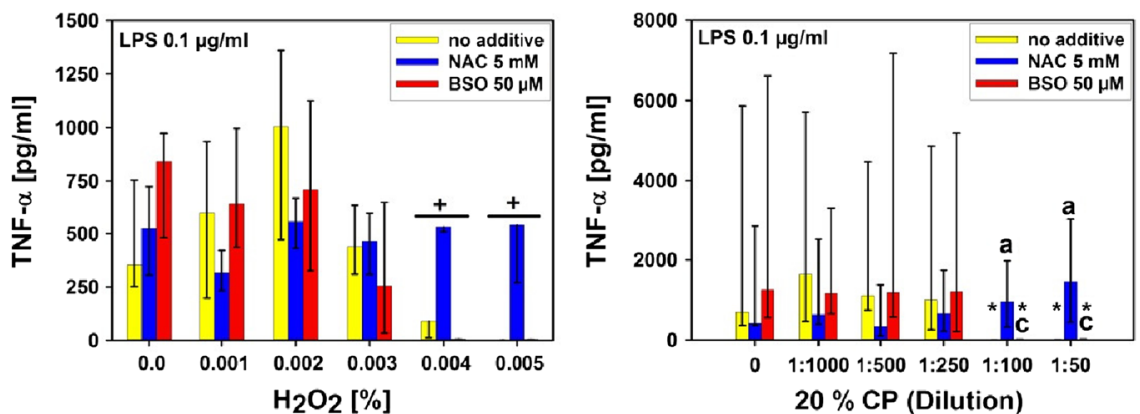

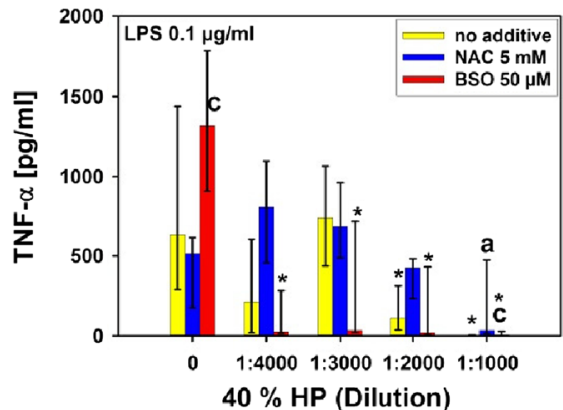

obtained with $20 \% \mathrm{CP}, 40 \% \mathrm{HP}$, or $\mathrm{H}_{2} \mathrm{O}_{2}$ in the presence of either NAC or BSO. "*" denote significant difference between median values obtained from untreated controls or controls in the presence of NAC or BSO and cultures treated with various matching dilutions of $20 \% \mathrm{CP}$ or $40 \% \mathrm{HP}$ extracts or concentrations of $\mathrm{H}_{2} \mathrm{O}_{2}$. "+" denotes no statistical analyses because of low sample size (2) obtained in four independent experiments as a consequence of severe cytotoxic effects 
powerful immune modulator, TNF- $\alpha$ is involved in systemic inflammation and is a member of the cytokines that stimulate the acute-phase reaction $[48,49]$. TNF- $\alpha$ gene expression was upregulated after 15 -min exposure by $17.5 \%$ hydrogen peroxide [49]. Thus, it can be concluded that even at non-cytotoxic concentrations of bleaching, gel extracts may increase an inflammatory reaction.

For all tested endpoints (cytotoxicity, cell surface markers, and $\mathrm{TNF}-\alpha$ ), the antioxidant NAC decreased the effects and the GSH inhibitor BSO increased them. BSO had a reverse effect, as it selectively inhibits the first step enzyme of GSH synthesis thus leading to the further antioxidant GSH depletion [32]. NAC is the $N$-acetyl derivative of the amino acid Lcysteine and is a precursor of the antioxidant glutathione; the thiol (sulfhydryl) group is responsible for the antioxidant effects $[34,50]$. Several effects are attributed to NAC as a potential protector against cytotoxicity and genotoxicity $[32,51]$. Furthermore, NAC blocks the intracellular generation of ROS preventing apoptosis [52]. So, the protective mechanism of NAC may be based on both reducing the $\mathrm{H}_{2} \mathrm{O}_{2}$ concentration in the exposure extract and counteracting the endogenous $\mathrm{H}_{2} \mathrm{O}_{2}$ being increased as a result of GSH depletion and the resulting ROS imbalance $[22,53]$. Our data demonstrate the central role of GSH.

It might be speculated to use NAC in bleaching preparations in order to reduce their cytotoxicity. This has, e.g., been proposed for acrylates, and indeed, a reduction of cytotoxicity was demonstrated for bone cements containing NAC [54]. However, for hydrogen peroxide-based bleaching agents, the use of the antioxidant NAC in such preparations may also reduce the bleaching effect, although NAC mainly acts intracellularly.

From our data, it is obvious that the mechanisms involved in the toxicity of bleaching agents are very similar if not identical with effects induced by pure hydrogen peroxide used as a positive control here. Cells were efficiently protected from cytotoxicity caused by pure hydrogen peroxide and extracts of the $40 \%$ hydrogen peroxide bleaching gel or $20 \%$ carbamide peroxide gel in the presence of NAC. Likewise, cytotoxic effects increased in the presence of BSO because the level of the non-enzymatic antioxidant glutathione was decreased as shown previously [32]. The weaker cytotoxic effect of the $20 \%$ carbamide peroxide gel compared to the $40 \%$ hydrogen peroxide bleaching gel indicated the lower amounts of peroxides included in the carbamide peroxide gel and the fact that the amount of hydrogen peroxide is lower because it originates form carbamide peroxide $\left(\mathrm{CH}_{6} \mathrm{~N}_{2} \mathrm{O}_{3}\right)$ decomposition. It has been suggested recently that levels of hydrogen peroxide exceeding the capacities of cellular antioxidants to maintain redox homeostasis are a major cause of oxidative stress leading to oxidative DNA damage which triggers apoptotic cell death [40]. Yet, no increase in the secretion of the proinflammatory cytokine TNF- $\alpha$ was detected in cells treated with appropriate concentrations of $40 \%$ hydrogen peroxide or $20 \%$ carbamide carbamide peroxide bleaching gels. It is possible that inflammation observed in human pulp tissues after bleaching is a consequence of necrosis rather than a response to bleaching agents per se [55]. The low $\mathrm{H}_{2} \mathrm{O}_{2}$ concentrations which increased LPS-stimulated TNF- $\alpha$ secretion in the present study may positively interfere with nitric oxide produced through LPS-induced activation of nitric oxide synthase (iNOS) [56].

\section{Conclusion}

All tested bleaching gels and the hydrogen peroxide were cytotoxic to murine macrophages at low concentrations. After a 1-h exposure, cells did not recover from the cytotoxic effects. This effect can be mitigated by the addition of an antioxidant as NAC and increased by the GSH inhibitor BSO. CD54 expression was increased with and without LPS stimulation indicating an initiation of an inflammatory reaction at non-cytotoxic concentrations.

Funding information The work was supported by the Department of Conservative Dentistry and Periodontology, University Clinics, University of Regensburg, Germany and by CAPES (Coordenação de Aperfeicoamento de Pessoal de Nível Superior), Brazil.

\section{Compliance with ethical standards}

Conflict of interest The authors declare that they have no conflict of interest.

Ethical approval This article does not contain any studies with human participants or animals performed by any of the authors.

Informed consent For this type of study, formal consent is not required.

\section{References}

1. Papathanasiou A, Kastali S, Perry RD, Kugel G (2002) Clinical evaluation of a $35 \%$ hydrogen peroxide in-office whitening system. Compend Contin Educ Dent 23(4):335-346

2. Lima AF, Ribeiro AP, Soares DG, Sacono NT, Hebling J, de Souza Costa CA (2013) Toxic effects of daily applications of $10 \%$ carbamide peroxide on odontoblast-like MDPC-23 cells. Acta Odontol Scand 71(5):1319-1325. https://doi.org/10.3109/00016357.2012.762992

3. Ribeiro DA, Marques ME, Salvadori DM (2006) Study of DNA damage induced by dental bleaching agents in vitro. Braz Oral Res 20(1):47-51. https://doi.org/10.1590/S1806-83242006000100009

4. Ubaldini AL, Baesso ML, Medina Neto A, Sato F, Bento AC, Pascotto RC (2013) Hydrogen peroxide diffusion dynamics in dental tissues. J Dent Res 92(7):661-665. https://doi.org/10.1177/ 0022034513488893

5. Carey CM (2014) Tooth whitening: what we now know. J Evid Based Dent Pract 14:70-76. https://doi.org/10.1016/j.jebdp. 2014.02.006 
6. Hanks CT, Fat JC, Wataha JC, Corcoran JF (1993) Cytotoxicity and dentin permeability of carbamide peroxide and hydrogen peroxide vital bleaching materials, in vitro. J Dent Res 72(5):931-938. https://doi.org/10.1177/00220345930720051501

7. Soares DG, Pastana JV, de Oliveira Duque CC, Dias Ribeiro AP, Basso FG, Hebling J, de Souza Costa CA (2014) Influence of adhesive restorations on diffusion of $\mathrm{H}_{2} \mathrm{O}_{2}$ released from a bleaching agent and its toxic effects on pulp cells. J Adhes Dent 16(2):123128. https://doi.org/10.3290/j.jad.a30688

8. Camargo SE, Valera MC, Camargo CH, Gasparoto Mancini MN, Menezes MM (2007) Penetration of 38\% hydrogen peroxide into the pulp chamber in bovine and human teeth submitted to office bleach technique. J Endod 33(9):1074-1077. https://doi.org/10. 1016/j.joen.2007.04.014

9. Matis BA, Moura HN, Cochran MA, Eckert GJ (2000) Clinical evaluation of bleaching agents of different concentrations. Quintessence Int 31(5):303-310

10. Machado LS, de Oliveira FG, Rocha EP, dos Santos PH, Briso AL, Sundefeld ML et al (2013) Clinical trial evaluating color change and tooth sensitivity throughout and following in-office bleaching. Int J Periodontics Restorative Dent 33(2):209-215. https://doi.org/ 10.11607/prd.1410

11. Reichl FX, Seiss M, Marquardt W, Kleinsasser N, Schweikl H, Kehe K, Hickel R (2008) Toxicity potentiation by $\mathrm{H}_{2} \mathrm{O}_{2}$ with components of dental restorative materials on human oral cells. Arch Toxicol 82(1):21-28. https://doi.org/10.1007/s00204-007-0226-1

12. Reichl FX, Durner J, Kehe K, Folwaczny M, Kleinsasser N, Schwarz M, El-Mahdy K, Hickel R (2003) Synergistic effects of $\mathrm{H}_{2} \mathrm{O}_{2}$ with components of dental restorative materials on gluconeogenesis in rat kidney tubules. Biomaterials 24:1909-1916

13. Furukawa M, K-Kaneyama JR, Yamada M, Senda A, Manabe A, Miyazaki A (2015) Cytotoxic effects of hydrogen peroxide on human gingival fibroblasts in vitro. Oper Dent 40(4):430-439. https:// doi.org/10.2341/14-059-L

14. Soares DG, Ribeiro AP, da Silveira Vargas F, Hebling J, de Souza Costa CA (2013) Efficacy and cytotoxicity of a bleaching gel after short application times on dental enamel. Clin Oral Investig 17(8): 1901-1909. https://doi.org/10.1007/s00784-012-0883-1

15. de Almeida LC, Soares DG, Gallinari MO, de Souza Costa CA, Dos Santos PH, Briso AL (2015) Color alteration, hydrogen peroxide diffusion, and cytotoxicity caused by in-office bleaching protocols. Clin Oral Investig 19(3):673-680. https://doi.org/10.1007/ s00784-014-1285-3

16. Soares DG, Sacono NT, Ribeiro AP, Basso FG, Scheffel DS, Hebling J, Costa CA (2015) Responses of dental pulp cells to a less invasive bleaching technique applied to adhesive-restored teeth. J Adhes Dent 17(2):155-161. https://doi.org/10.3290/j.jad.a33892

17. Daroui P, Desai SD, Li TK, Liu AA, Liu LF (2004) Hydrogen peroxide induces topoisomerase 1-mediated DNA damage and cell death. J Biol Chem 279(15):14587-14594. https://doi.org/10.1074/ jbc.M311370200

18. Nanavaty UB, Pawliczak R, Doniger J, Gladwin MT, Cowan MJ, Logun C, Shelhamer JH (2002) Oxidant-induced cell death in respiratory epithelial cells is due to DNA damage and loss of ATP. Exp Lung Res 28(8):591-607. https://doi.org/10.1080/ 01902140260426715

19. Filho LCC, Costa CC, Sória ML, Taga R (2002) Effect of home bleaching and smoking on marginal gingival epithelium proliferation: a histologic study in women. J Oral Pathol Med 31(8):473480. https://doi.org/10.1034/j.1600-0714.2002.00110.x

20. IARC Monographs on the Evaluation of Carcinogenic Risks to Humans - Re-evaluation of Some Organic Chemicals, Hydrazine and Hydrogen Peroxide. Volume 71. International Agency for Research on Cancer (1999) Lyon, France. https://monographs. iarc.fr/ENG/Monographs/vol71/mono71.pdf
21. Riedl MA, Nel AE (2008) Importance of oxidative stress in the pathogenesis and treatment of asthma. Curr Opin Allergy Clin Immunol 8(1):49-56. https://doi.org/10.1097/ACI. 0b013e3282f3d913

22. Pazmandi K, Magyarics Z, Boldogh I, Csillag A, Rajnavolgyi E, Bacsi A (2012) Modulatory effects of low-dose hydrogen peroxide on the function of human plasmacytoid dendritic cells. Free Radic Biol Med 52(3):635-645. https://doi.org/10.1016/j.freeradbiomed. 2011.11.022

23. Deng G, Lin H, Seidman A, Fornier M, D'Andrea G, Wesa K, Yeung S, Cunningham-Rundles S, Vickers AJ, Cassileth B (2009) A phase I/II trial of a polysaccharide extract from Grifola frondosa (Maitake mushroom) in breast cancer patients: immunological effects. J Cancer Res Clin Oncol 135(9):1215-1221. https://doi.org/ 10.1007/s00432-009-0562-Z

24. Heo SJ, Yoon WJ, Kim KN, Oh C, Choi YU, Yoon KT, Kang DH, Qian ZJ, Choi IW, Jung WK (2012) Anti-inflammatory effect of fucoxanthin derivatives isolated from Sargassum siliquastrum in lipopolysaccharide-stimulated RAW 264.7 macrophage. Food Chem Toxicol 50(9):3336-3342. https://doi.org/10.1016/j.fct. 2012.06.025

25. Vaz MM, Lopes LG, Cardoso PC, Souza JB, Batista AC, Costa NL, Torres ÉM, Estrela C (2016) Inflammatory response of human dental pulp to at-home and in-office tooth bleaching. J Appl Oral Sci 24(5):509-517. https://doi.org/10.1590/1678-775720160137

26. D'Antò V, Eckhardt A, Hiller KA, Spagnuolo G, Valletta R, Ambrosio L, Schmalz G, Schweikl H (2009) The influence of $\mathrm{Ni}(\mathrm{II})$ on surface antigen expression in murine macrophages. Biomaterials 30(8):1492-1501. https://doi.org/10.1016/j. biomaterials.2008.12.004

27. Zanoni I, Ostuni R, Barresi S, Di Gioia M, Broggi A, Costa B et al (2012) CD14 and NFAT mediate lipopolysaccharide-induced skin edema formation in mice. J Clin Invest 122(5):1747-1757. https:// doi.org/10.1172/JCI60688

28. Roebuck KA, Finnegan A (1999) Regulation of intercellular adhesion molecule-1 (CD54) gene expression. J Leukoc Biol 66(6): 876-888

29. Mulvihill NT, Foley JB, Crean P, Walsh M (2002) Prediction of cardiovascular risk using soluble cell adhesion molecules. Eur Heart J 23(20):1569-1574. https://doi.org/10.1053/euhj.2002.3188

30. Eckhardt A, Harorli T, Limtanyakul J, Hiller KA, Bosl C, Bolay C, Reichl FX, Schmalz G, Schweikl H (2009) Inhibition of cytokine and surface antigen expression in LPS-stimulated murine macrophages by triethylene glycol dimethacrylate. Biomaterials $30(9)$ : 1665-1674. https://doi.org/10.1016/j.biomaterials.2008.09.024

31. Schweikl H, Spagnuolo G, Schmalz G (2006) Genetic and cellular toxicology of dental resin monomers. J Dent Res 85(10):870-877. https://doi.org/10.1177/154405910608501001

32. Krifka S, Hiller KA, Spagnuolo G, Jewett A, Schmalz G, Schweikl $\mathrm{H}$ (2012) The influence of glutathione on redox regulation by antioxidant proteins and apoptosis in macrophages exposed to 2hydroxyethyl methacrylate (HEMA). Biomaterials 33(21):51775186. https://doi.org/10.1016/j.biomaterials.2012.04.013

33. Zhang T, Tang M, Kong L, Li H, Zhang T, Zhang S, Xue Y, Pu Y (2012) Comparison of cytotoxic and inflammatory responses of pristine and functionalized multi-walled carbon nanotubes in RAW 264.7 mouse macrophages. J Hazard Mater 219-220:203212. https://doi.org/10.1016/j.jhazmat.2012.03.079

34. Kumar SM, Swaminathan K, Clemens DL, Dey A (2015) GSH protects against oxidative stress and toxicity in VL-17A cells exposed to high glucose. Eur J Nutr 54(2):223-234. https://doi.org/ 10.1007/s00394-014-0703-2

35. Krifka S, Spagnuolo G, Schmalz G, Schweikl H (2013) A review of adaptive mechanisms in cell responses towards oxidative stress caused by dental resin monomers. Biomaterials 34(19):45554563. https://doi.org/10.1016/j.biomaterials.2013.03.019 
36. Goldberg M, Grootveld M, Lynch E (2010) Undesirable and adverse effects of tooth-whitening products: a review. Clin Oral Investig 14(1):1-10. https://doi.org/10.1007/s00784-009-0302-4

37. Cavalcanti BN, Rode SM, Marques MM (2005) Cytotoxicity of substances leached or dissolved from pulp capping materials. Int Endod J 38(8):505-509. https://doi.org/10.1111/j. 1365-2591.2005.00967.x

38. ISO 10993-5 Biological evaluation of medical devices - Part 5: Tests for in vitro cytotoxicity. International Organization for Standardization, 2009

39. Schmalz G, Krifka S, Schweikl H (2011) Toll-like receptors, LPS, and dental monomers. Adv Dent Res 23(3):302-306. https://doi. org $/ 10.1177 / 0022034511405391$

40. Schweikl H, Petzel C, Bolay C, Hiller KA, Buchalla W, Krifka S (2014) 2-Hydroxyethyl methacrylate-induced apoptosis through the ATM- and p53-dependent intrinsic mitochondrial pathway. Biomaterials 35(9):2890-2904. https://doi.org/10.1016/j. biomaterials.2013.12.044

41. Goldberg M, Grootveld M, Lynch E (2010) Undesirable and adverse effects of tooth-whitening products: a review. Clin Oral Investig 141:1-10

42. Coldebella CR, Ribeiro AP, Sacono NT, Trindade FZ, Hebling J, Costa CA (2009) Indirect cytotoxicity of a $35 \%$ hydrogen peroxide bleaching gel on cultured odontoblast-like cells. Braz Dent J 20(4): 267-274. https://doi.org/10.1590/S0103-64402009000400001

43. Dantas CM, Vivan CL, Ferreira LS, Freitas PM, Marques MM (2010) In vitro effect of low intensity laser on the cytotoxicity produced by substances released by bleaching gel. Braz Oral Res 24(4):460-466. https://doi.org/10.1590/S180683242010000400015

44. Baldea I, Olteanu DE, Filip AG, Cenariu M, Dudea D, Tofan A, Alb C, Moldovan M (2017) Toxicity and efficiency study of plant extracts-based bleaching agents. Clin Oral Investig 21(4):13151326. https://doi.org/10.1007/s00784-016-1882-4

45. Lee GP, Lee MY, Lum SO, Poh RS, Lim KC (2004) Extraradicular diffusion of hydrogen peroxide and $\mathrm{pH}$ changes associated with intracoronal bleaching of discoloured teeth using different bleaching agents. Int Endod J 37(7):500-506. https://doi.org/10. $1111 / j .1365-2591.2004 .00838 . x$

46. Lawson C, Wolf S (2009) ICAM-1 signaling in endothelial cells. Pharmacol Rep 61(1):22-32. https://doi.org/10.1016/S17341140(09)70004-0
47. Riches DW, Chan ED, Winston BW (1996) TNF-alpha-induced regulation and signalling in macrophages. Immunobiology 95: $477-490$

48. Gu W, Chen J, Yang L, Zhao KN (2012) TNF- $\alpha$ promotes IFN- $\gamma$ induced CD40 expression and antigen process in Myb-transformed hematological cells. Sci World J 2012:621969

49. Soares DG, Marcomini N, Basso FG, Pansani TN, Hebling J, de Souza Costa CA (2016) Indirect cytocompatibility of a lowconcentration hydrogen peroxide bleaching gel to odontoblast-like cells. Int Endod J 49(1):26-36. https://doi.org/10.1111/iej.12426

50. Weiss JF, Landauer MR (2000) Radioprotection by antioxidants. Ann N Y Acad Sci 899:44-60

51. Reliene R, Pollard JM, Sobol Z, Trouiller B, Gatti RA, Schiestl RH (2009) N-acetyl cysteine protects against ionizing radiation-induced DNA damage but not against cell killing in yeast and mammals. Mutat Res 665(1-2):37-43. https://doi.org/10.1016/j.mrfmmm. 2009.02.016

52. Han MH, Park C, Jin CY, Kim GY, Chang YC, Moon SK et al (2013) Apoptosis induction of human bladder cancer cells by sanguinarine through reactive oxygen species mediated up regulation of early growth response Gene1. PLoS One 8:63425

53. Lee DS, Li B, Kim KS, Jeong GS, Kim EC, Kim YC (2013) Butein protects human dental pulp cells from hydrogen peroxide-induced oxidative toxicity via Nrf2 pathway-dependent heme oxygenase-1 expressions. Toxicol in Vitro 27(2):874-881. https://doi.org/10. 1016/j.tiv.2013.01.003

54. Minamikawa H, Yamada M, Iwasa F, Ueno T, Deyama $\mathrm{Y}$, Suzuki K, Yawaka Y, Ogawa T (2010) Amino acid derivative-mediated detoxification and functionalization of dual cure dental restorative material for dental pulp cell mineralization. Biomaterials 31(28):7213-7225. https://doi.org/10. 1016/j.biomaterials.2010.06.018

55. Costa CA, Riehl H, Kina JF, Sacono NT, Hebling J (2010) Human pulp responses to in-office tooth bleaching. Oral Surg Oral Med Oral Pathol Oral Radiol Endod 109(4):59-64

56. Blaser H, Dostert C, Mak TW, Brenner D (2016) TNF and ROS crosstalk in inflammation. Trends Cell Biol 26(4):249-261. https:// doi.org/10.1016/j.tcb.2015.12.002 